\title{
Pengaruh Kepemimpinan Terhadap Kinerja dan Kepuasan Kerja Karyawan
} Pada PT. Gada Rajawali Dunia

\author{
Nurmin Arianto \\ Dosen Fakultas Ekonomi Universitas Pamulang \\ Email : nurmin1989@gmail.com
}

\begin{abstract}
ABSTRAK
Penelitian ini bertujuan untuk mengetahui pengaruh kepemimpinan terhadap kinerja karyawan dan pengaruh kepemimpinan terhadap kepuasan kerja serta untuk mengetahui pengaruh kinerja karyawan terhadap kepuasan kerja.

Penelitian ini bersifat Asosiatif dan teknik pengumpulan data dengan menggunakan data primer berupa kuisioner yang disebar pada seluruh karyawan yang berkerja di perusahaan dengan jumlah populasi sebanyak 42 dan teknik sampling menggunakan sampling jenuh.

Hasil penelitian menunjukan bahwa kepemimpinan memiliki pengaruh yang positif dan signifikan terhadap kinerja karyawan dan kepimimpinan memiliki pengaruh yang positif dan signifikan terhadap kepuasan kerja serta kinerja karyawan memiliki pengaruh yang psotif dan signifikan terhadap kepuasan kerja.
\end{abstract}

Kata Kunci: Kepemimpinan, Kinerja, Kepuasan Kerja 


\section{PENDAHULUAN}

\section{A. Latar Belakang Masalah}

Pengelolaan sumber daya manusia sangat diperlukan untuk efektivitas sumber daya manusia dalam suatu organisasi. Tujuan dari hal tersebut adalah untuk memberikan kepada organisasi satuan kerja yang efektif untuk mencapai tujuan studi tentang manajemen perusahaan bagaimana seharusnya perusahaan dapat mengembangkan, menggunakan dan memelihara karyawan dalam kualitas dan kuantitas yang tetap. Oleh karena itu pihak manajemen perusahaan harus mampu memahami bagaimana cara terbaik dalam mengelola karyawan yang berasal dari latar belakang, keahlian, dan kemampuan yang berbeda-beda sehingga karyawan dapat bekerja sesuai dengan keahlian dan jenis pekerjaan yang diberikan, maka dari itu pemimpin harus dapat menjadi panutan untuk bawahanya dan memberikan arahan yang baik serta masukan kepada bawahan dan mampu mendengarkan aspirasi bawahanya, kempemimpinan yang dimaksud adalah rangkaian kegiatan penataan berupa kemampuan mempengaruhi perilaku orang lain dalam situasi tertentu agar bersedia bekerja sama untuk mencapai tujuan yang telah ditetapkan, (Sutarto, 2012:25).

Berdasarkan hasil oberservasi yang dimana hubungan antara pemimpin dengan karyawanya masih kurnag harmonis dan kurang tegasnya atasan terhadap bawahan jika lalai dalam menyelesaikan pekerjaan, sehingga menyebabkan karyawan dapat kurang memahami tujuan dari pekerjaan yang di jalankannya dan hal ini berakibat kepada kinerja karyawan yang menurun dan hasil kerja yang tidak seusai dengan target kerja yang telah ditetapkan, kinerja merupakan gambaran mengenai tingkat pencapain pelaksanaa suatu program kegiatan atau kebijakan dalam mewujudkan sasaran, tujuan, visi dan misi organisasi yang di tuangkan dalam perencanaan stratgeis suatu organisasai, Moeheriono (2012:95). Maka dari itu apabila kinerja karyawan yang baik dan seusai dengan tujuan perusahaan maka karyawan juga akan merasa puas dengan hasil kerja yang di capai nya, namun yang ada di perusahaan dimana karyawan merasa kurang puasnya terhadap hasil kerja yang telah di selesaikan disisi lain beban kerja yang tidak seusai dengan jabatan yang di milikinya maka dari itu kepuasan kerja berhubungan dengan perasaan atau sikap seseorang mengenai pekerjaan itu sendiri, gaji, kesempatan promosi atau pendidikan, pengawasan, rekan kerja, beban kerja dan lain-lain, Ricahard, Robert dan Gordon (2012:312,337).

Sehingga kepuasan keja menjadi masalah yang cukup menarik dan penting, karena terbukti besar manfaatnya bagi kepentingan individu, industri dan masyarakat, Edy Sutrisno (2014:73). Maka dari itu jika pemimpin yang sesuai dengan criteria dari karyawanya maka karyawan dapat bekerja seuai 
dengan arahan dan tujuan yang telah ditetapkan perusahaan dengan arahan dari pemimpin sehingga dapat meningkatkan kinerja karyawan dan berakibat juga terhadap kepuasan kerja karyawanya. Maka dari itu penulis tertarik untuk mengambil penelitian ini dengan judul "Pengaruh Kempimpin terhadap Kinerja Karyawan dan Kepuasan Kerja Pada PT Gada Rajawali Dunia"

\section{B. Identifikasi Masalah}

Berdasarkan alatar belakang masalah yang ada maka penluis mencoba mengidentifikasi masalah-masalah yang ada dianataranya adalah:

1. Hubungan atasan dengan bawahan kurang harmonis

2. Kurang tegasnya atasan terhadap bawahan jika lalai dalam menyelesaikan pekerjaan

3. Kinerja karyawan yang menurun

4. Hasil kerja yang tidak seusai dengan target kerja yang telah ditetapkan

5. Kurang puasnya terhadap hasil kerja yang telah di selesaikan

6. Beban kerja yang tidak seusai dengan jabatan yang di milikinya

\section{Rumusan Masalah}

Berdasarkan latar belakang masalah dan identifkasi yang ada maka rumusan masalah yang diperoleh ialah:

1. Seberapa besar pengaruh kepemimpinan terhadap kinerja karyawan?
2. Seberapa besar pengaruh kepemimpin terhadap kepuasan kerja

3. Seberapa besar pengaruh kinerja karyawan terhadap kepuasan kerja?

D. Tujuan Penelitian

Tujuan dari penelitian ini adalah:

1. Untuk mengetahui seberapa besar pengaruh kepemimpinan terhadap kinerja karyawan

2. Untuk mengetahui seberapa besar pengaruh kepemimpinan terhadap kepuasan kerja

3. Untuk mengetahui seberapa besar pengaruh kinerja karyawan terhadap kepuasan kerja

\section{E. Kerangka Berpikir dan} Hipotesis Penelitian

Menurut Sugiyono (2012:89)

Kerangka berfikir merupakan sintesa tentang hubungan antara variabel yang disusun dari berbagai teori yang telah dideskrpsikan. Variabel dibedakan menjadi dua, yaitu variabel independen atau variable bebas (X) dan variable dependen atau variabel terikat (Y). Variabel independen atau variabel bebas adalah variabel yang mempengaruhi atau yang menjadi sebab perubahannya atau tumbulnya variabel dependen (variabel terikat). Sedangkan variabel dependen atau variabel terikat adalah variabel yang dipengaruhi atau menjadi akibat karena adanya variabel bebas (Sugiyono,2012: 59). Dalam penelitian ini yang menjadi 
variabel independennya adalah Kepemimpinan (X), sedangkan yang menjadi variabel dependennya adalah Kinerja Karyawan $\left(\mathrm{Y}_{1}\right)$ dan Kepuasan $\operatorname{Kerja}\left(\mathrm{Y}_{2}\right)$.

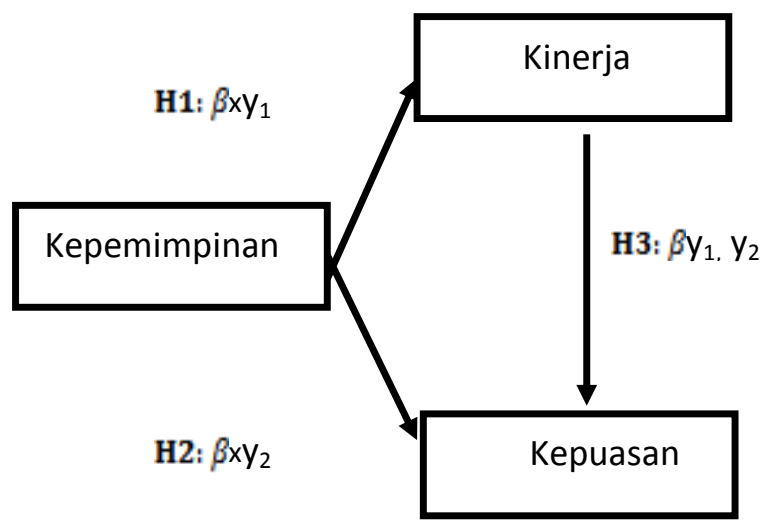

Keterangan:

H1: $\beta \mathrm{xy}_{1:}$ Terdapat pengaruh Kepemimpinan terhadap Kinerja Karyawan

H2: $\beta \mathrm{xy}_{2}$ : Terdapat pengaruh Kepemimpinan terhadap

Kepuasan Kerja

H3: $\beta \mathrm{y}_{1}, \quad \mathrm{y}_{2}$ : Terdapat pengaruh Kinerja terhadap Kepuasan Kerja

\section{LANDASAN TEORI}

\section{A. Kepemimpinan}

Kepemimpinan meruapakan rangkaian kegiatan penataan berupa kemampuan mempengaruhi perilaku orang lain dalam situasi tertentu agar bersedia bekerja sama untuk mencapai tujuan yang telah ditetapkan, (Sutarto, 2012:25). Sedangkan menurut Hasibuan (2011:157), pemimpin adalah seseorang yang mempergunakan wewenang dan kepemimpinannya untuk mengarahkan orang lain serta bertanggung jawab atas pekerjaan orang tersebut dalam mencapai suatu tujuan.
Sebagaimana diungkapkan

Sedarmayanti

(2009-119)

bahwa pemimpin (leader) adalah

1. Seseorang yang mampu mempengaruhi orang lain untuk melakukan atau tidak melakukan sesuatu sesuai yang diinginkan.

2. Seseorang yang menjalankan kepemimpinan sedangkan pimpinan (manager) adalah seseorang yang menjalankan manajemen. Orang yang sama harus menjalankan dua hal secara efektif: manajemen dan kepemimpinan.

3. Orang yang melakukan atau menjalankan kepemimpinan.

4. Kata "pemimpin" mencerminkan kedudukan seseorang atau kelompok orang pada hierarki tertentu dalam organisasi, yang mempunyai bawahan, karena kedudukan yang bersangkutan memdapatkan

atau mempunyai kekuasaan formal, dan tanggung jawab.

Veitzhal Rivai (2012:53) mengemukan bahwa seorang pemimpin dalam meng implementasikan kepemimpinannya harus mampu secara dewasa melaksanakan kedewasaan terhadap instansi atau organisasinya, kepemimpinan dibagi kedalam lima dimensi dan sembilan indikator, yaitu :

1. Kemampuan untuk membina kerjasama dan hubungan yang baik

a. Membina kerjasama dan hubungan baik dengan bawahan dalam pelaksanaan tugas yang 
menjadi tanggung jawab masing-masing

b. Kemampuan seorang pemimpin dalam memotivasi bawahannya

2. Kemampuan yang efektivitas

a. Mampu menyelesikan tugas diluar kemampuan

b. Hadir tepat waktu dan tidak terlambat

3. Kepemimpinan yang partisipatif

a. Pengambilan keputusan secara musyawarah

b. Dapat menyelesaikan masalah secara tepat

4. Kemampuan dalam mendelegasikan tugas atau waktu

a. Bersedia untuk membawa kepentingan pribadi dan organisasi kepada kepentingan yang lebih luas, yaitu kepentingan organisasi menggunakan waktu sisa untuk keperluan pribadi

b. Mampu dalam menyelesaikan tugas sesuai dengan target

5. Kemampuan dalam mendelegasikan tugas atau wewenang

a. Tanggung jawab seorang pemimpin dalam menyelesaikan tugas mana yang harus ditangani sendiri dan mana yang harus ditangani secara kelompok.

b. Memberikan bimbingan dan pelatihan dalam pengambilan keputusan

\section{B. Kinerja Karyawan}

Kinerja merupakan gambaran mengenai tingkat pencapain pelaksanaa suatu program kegiatan atau kebijakan dalam mewujudkan sasaran, tujuan, visi dan misi organisasi yang di tuangkan dalam perencanaan stratgeis suatu organisasai, Moeheriono (2012;95). Sedangakan menurut Mangkunegara (2010:2), berpendapat bahwa kinerja adalah prestasi kerja atau hasil kerja baik kualitas maupun kuantitas yang dicapai SDM per satuan periode waktu dalam melaksanakan tugas kerjanya dengan tanggung jawab yang diberikan kepadanya.

Maka dari itu kinerja karyawan merupakan hal yang terpenting dalam perusahaan sekaligus sebgai penentu efektif tidak kinerja didalam perusahaan, apabila kinerja karyawan tidak baiak maka kinerja perusahaanpun secara otomatis tidak baik.Begitupula sebalik nya. Kinerja perusahaan yang dicerminkan oleh kinerja karyawan atau dengan kata lain, kinerja merupakan hasil kerja kongkrit yang dapat diamati dan dapat diukur. Dimensi dan indikator kinerja karyawan menurut Sedarmayanti (2013:260), mengemukakan bahwa :

1. Kualitas Pekerjaan Kualitas pekerjaan yaitu kualitas kerja yang dicapai berdasarkan syaratsyarat kesesuaian dan kesiapannya. Dimana hasil aktivitas yang dilakukan mendekati sempurna yang 
meliputi ketelitian dalam bekerja dan hasil pekerjaan yang memenuhi standar, seperti :
a. Ketelitian dalam melaksanakan tugas
b. Hasil kerja yang diperoleh sesuai dengan target

2. Kuantitas Pekerjaan Jumlah yang dihasilkan dinyatakan dalam istilah jumlah unit, jumlah siklus aktivitas yang diselesaikan, misalnya :
a. Kecepatan dalam menyelesaikan tugas
b. Mampu dalam menyelesaikan masalah pekerjaan

3. Tanggung jawab Tanggung jawab yaitu kesediaan untuk memperbaiki

kesalahankesalahan yang dialami dalam suatu pekerjaan, misalnya :
a. Mengambil keputusan secara musyawarah

4. Kemampuan Bekerjasama Kemampuan bekerja sama yaitu kesediaan untuk bekerjasama dengan orang lain sesama anggota organisasi, misalnya :

a. Hubungan antara atasan dengan pegawai

b. Hubungan antara sesama pegawai

5. Inisiatif Kemampuan dalam menyelesaikan suatu pekerjaan sesuai dengan waktu yang sudah ditentukan dan mampu menghasilkan pekerjaan sesuai dengan target, misalnya : a. Melakukan pekerjaan tanpa menunggu perintah dari atasan

b. Memberikan solusi dalam menghadapi masalah pekerjaan

c. Memberikan ide-ide baru sebelum menyelesaikan pekerjaan

\section{Kepuasan Kerja}

Kepuasan kerja berhubungan dengan perasaan atau sikap seseorang mengenai pekerjaan itu sendiri, gaji, kesempatan promosi atau pendidikan, pengawasan, rekan kerja, beban kerja dan lain-lain, Ricahard, Robert dan Gordon (2012:312,337). Kepuasan keja menjadi masalah yang cukup menarik dan penting, karena terbukti besar manfaatnya bagi kepentingan individu, industri dan masyarakat, Edy Sutrisno (2014:73).

Bagi individu, penelitian tentang sebab-sebab dan sumbersumber kepuasan kerja memungkinkan timbulnya usahausaha peningkatan kebahagiaan hidup mereka. Bagi industri, penelitian mengenai kepuasan kerja dilakukan dalam rangka usaha peningkatan produksi dan pengaruh biaya melalui perbaikan sikap dan tingkah laku karyawannya. Selanjutnya, masyarakat tentu akan menikmati hasil kapasitas maksimum dari industri serta naiknya nilai manusia di dalam konteks pekerjaan. Sedangkan kepuasan kerja menurut Dadang (2013:15) adalah keadaan emosional yang menyenangkan atau tidak 
menyenangkan terhadap

pekerjaan, kepuasan kerja

mencerminkan perasaan

seeorang terhadap terhadap

pekerjaannya.

Dimensi dan indicator kepusan kerja menurut Kreitner dan Kinichi (2010) lima dimensi kepuasan kerja adalah sebagai berikut :

1. Need fulfillment (pemenuhan kebutuhan). Model ini mengajukan bahwa kepuasan ditentukan tingkatan karakteristik pekerjaan yang memungkinkan kesempatan pada individu untuk memenuhi kebutuhannya, yaitu terdiri atas :

a. Sikap terhadap pekerjaan : apakah individu merasa pekerjaa yang dilakukannya membuat dampak positif bagi dirinya

b. Penilaian terhadap pekerjaan : pekerjaan yang dilakukan oleh pekerja membuat ia mampu memenuhi kebutuhan hidupnya sehingga bekerja ditempat ia bekerja memberikan hal yang lebih bagi dia.

2. Discrepancies (perbedaan). Model ini menyatakan bahwa kepuasan merupakan suatu hasil memenuhi harapan. Pemenuhan harapan mencerminkan perbedaan antara apa yang diharapkan dan yang diperoleh individu dari pekerjaan. Apabila harapan lebih besar daripada apa yang diterima, orang akan tidak puas. Sebaliknya diperkirakan individu akan puas apabila mereka menerima manfaat diatas harapan. Hal ini berkaitan dengan :

a. Penerimaan karyawan terhadap kompensasi yang diberikan perusahaan

b. Penerimaan karyawan terhadap jaminanjaminan yang diberikan oleh perusahaan

3. Value attainment (pencapaian nilai). Gagasan value attainment adalah bahwa kepuasan merupakan hasil dari persepsi pekerjaan memberikan pemenuhan nilai kerja individual yang penting. Hal ini terlihat dengan :

a. Kepuasan pribadi atas pencapaian dalam mengerjakan tugastugasnya

b. Menerima reward dari atasan atas hasil yang telah dicapainya

4. Equity (keadilan). Dalam model ini dimaksudkan bahwa kepuasan merupakan fungsi dari seberapa adil individu diperlakukan di tempat kerja. Kepuasan merupakan hasil dari persepsi orang bahwa perbandingan antara hasil kerja dan inputnya relatif lebih menguntungkan dibandingkan dengan perbandingan antara keluaran dan masukkan pekerjaan lainnya. Hal ini berkaitan dengan promosi ditempat kerja atas pencapaian atau kinerja yang dicapai oleh karyawan itu sendiri. 
a. Promosi ditempat kerja, untuk naik ke jabatan yang lebih tinggi

b. Mendapatkan kesempatan yang sama, dalam satu tim untuk semua anggota untuk merasakan pelatihan dan pengembangan diri

5. Dispositional/genetic components (komponen genetik). Beberapa rekan kerja atau teman tampak puas terhadap variasi lingkungan kerja, sedangkan lainnya kelihatan tidak puas. Model ini didasarkan pada keyakinan bahwa kepuasan kerja sebagian merupakan fungsi sifat pribadi dan faktor genetik. Model menyiratkan perbedaan individu hanya mempunyai arti penting untuk menjelaskan kepuasan kerja seperti halnya karakteristik lingkungan pekerjaan. Hal ini berkaitan dengan :

a. Sikap karyawan, yang menggambarkan perasaan pribadinya terhadap lingkungan kerjanya.

b. Kepercayaan karyawan terhadap perusahaan untuk bisa membuat dirinya lebih maju lagi.

\section{METODOLOGI PENELITIAN}

\section{A. Metode Penelitian}

Penelitian ini dilakukan pada karyawan yang bekerja di PT Gada Rajawali Dunia, sedangakan metode penelitian yang digunakan adalah metode asosiatif dengan pendekatan survey dan obervasi langsung hal ini karena adanya variabelvariabel yang akan ditelah hubungannya serta tujuan untuk menyajikan gambaran secara terstruktur, faktual dan akurat mengenai fakta-fakta serta hubungan variabel yang diteliti. Penelitian Asosiatif merupakan penelitian yang bertujuan untuk mengetahui hubungan dua variabel atau lebih. Dalam penelitian ini akan dibangun suatu teori yang dapat berfungsi untuk menjelaskan, meramalkan, dan mengontrol suatu gejala. Sugiyono (2012:36).

Ada dua instrumen dalam metode survey, yaitu kuesioner (pertanyaan tertulis) dan wawancara (pertanyaan lisan). Kuesioner dapat langsung dikomunikasikan kepada dan dikumpulkan dari responden (secara perseorangan) atau dapat juga dikomunikasikan dan dikumpulkan melalui pos. Wawancara dapat dilakukan dengan komunikasi tatap muka atau telepon (Indriantoro, 2002:26). Penelitian ini yaitu menggunakan kuesioner metode tertutup. Data yang diperoleh kemudian diolah, dianalisis dan diproses lebih lanjut dengan dasar teoriteori yang telah dipelajari. Sedangkan analisis dilakukan melakukan melalui pendekatan kuantitatif dengan menggunakan metode statik yang relevan untuk menguji hipotesis.

\section{B. Operasional Variabel \\ Penelitian}

Variabel penelitian adalah sebagai berikut: "Variabel penelitian pada dasarnya adalah segala sesuatu yang berbentuk apa saja yang ditetapkan oleh 
peneliti untuk dipelajari sehingga diperoleh informasi tentang hal tersebut, kemudian ditarik kesimpulannya.", Sugiyono (2012:2).

Dalam penelitian ini, variabel-variabel yang akan diteliti

adalah :

1. Variabel $\mathrm{x}$ atau variabek bebas (independen) merupakan variabel yang mempengaruhi variabel lain. Dalam penelitian ini yang merupakan variabel bebas adalah

Kepemimpinan.

2. Variabel $\mathrm{Y}$ atau yang disebut dengan variabel terikat (dependen variabel), variabel terikat merupakan variabel yang

dipengaruhi oleh variabel lain. Dalam penelitian ini yang merupakan variabel terikat adalah Kinerja dan Kepuasan Kerja .

\section{Skala Pengukuran}

Menurut Ridwan (2007:84) definisi Skala Ordinal adalah: "Skala Ordinal adalah skala yang didasarkan pada rangking, diurutkan dari jenjang yang lebih tinggi sampai jenjang yang terendah atau sebaliknya." Dari pengertian diatas dapat ditarik kesimpulan bahwa dalam penelitian ini digunakan skala ordinal karena, pengambilan data nya diambil berdasarkan rangking, dari jenjang yang lebih tinggi sampai jenjang yang terendah atau sebaliknya.

Dalam operasionalisasi variabel ini, variabel $\mathrm{X}$ diukur oleh instrumen pengukur dalam bentuk kuesioner yang memenuhi pernyataanpernyataan tipe skala likert. Skala likert menurut Sugiyono (2010:93) adalah sebagai berikut : "Skala Likert digunakan untuk mengukur sikap, pendapat dan persepsi seseorang atau sekelompok orang tentang fenomena sosial." Untuk setiap pilihan jawaban diberi skor, maka responden harus menggambarkan, mendukung pernyataan. Untuk digunakan jawaban yang dipilih.

Dengan skala Likert, maka variabel yang akan diukur dijabarkan menjadi indikator variabel. Kemudian indikator tersebut dijadikan sebagai titik tolak ukur menyusun item-item instrumen yang dapat berupa pertanyaan atau pernyataan.

Tabel 3.1

Skala Penilaian

\begin{tabular}{|l|l|c|}
\hline No & Keterangan & Skor \\
\hline 1. & Sangat Setuju & $\mathbf{5}$ \\
2. & Setuju & 4 \\
3 & Ragu-ragu & $\mathbf{3}$ \\
4. & Tidak Setuju & $\mathbf{2}$ \\
5. & Sangat Tidak Setuju & $\mathbf{1}$ \\
\hline
\end{tabular}

Sumber Sugiyono, 2010:94)

\section{Sumber Data}

Sumber data dalam penelitian ini adalah sumber data primer, yaitu data yang diperoleh secara langsung dengan cara menyebarkan kuesioner kepada responden yang menjadi sample untuk mengetahui tanggapan tentang penelitian yang akan diteliti. Selain itu data primer juga meliputi dokumen-dokumen perusahaan berupa sejarah 
perkembangan perusahaan, struktur organisasi, dan data-data statistik mengenai jumlah pegawai dan lain-lain yang berhubungan dengan penelitian ini.

1. Data Primer Definisi yang diungkapkan oleh Sugiyono (2010:137), mendefinisikan bahwa: "Sumber primer adalah sumber data yang lansung memberikan data kepadapengumpul data". Sedangkan menurut Andi Supangat (2010:2) mendefinisikan bahwa: "Data Primer yaitu data yang diperoleh secara langsung dari objek yang diteliti, baik dari objek individual (responden) maupun dari suatu instansi yang dengan sengaja melakukan pengumpulan data dari instansi-instansi atau badan lainnya untuk keperluan penelitian dari pengguna". Berdasarkan pengertian di atas, dapat disimpulkan bahwa sumber data primer merupakan data yang diperoleh secara langsung dari obyek yang diteliti baik dari pribadi (responden) maupun dari suatu instansi yang mengolah data untuk keperluan penelitian, seperti dengan cara melakukan wawancara secara langsung dengan pihak-pihak yang berhubungan dengan penelitian yang dilakukan. Data primer diperoleh dengan mengadakan penelitian dan kuesioner

2. Data Sekunder Definisi data sekunder menurut Jogiyanto
(2010:137) mendefinisikan bahwa : "Sumber data sekunder merupakan sumber yang tidak langsung memberikan data kepada pengumpul data, misalnya lewat orang lain atau lewat dokumen". Sedangkan menurut Andi Supangat (2010:2) mendefinisikan bahwa: "Data sekunder adalah data yang diperoleh secara tidak langsung untuk mendapatkan informasi (keterangan) objek yang diteliti, biasanya datatersebut diperoleh dari tangan kedua baik dari objek secara individual (responden) maupun dari suatu badan (instansi) yang dengan sengaja melakukan pengumpulan data dari instansi-instansi atau badan lainnya untuk keperluan penelitian dari para pengguna"

\section{E. Populasi dan sampel}

Menurut
$\begin{aligned} & \text { Sugiyono } \\ & \text { bukunya }\end{aligned}$
mengemukakan
populasi adalah: $\begin{array}{r}\text { mengenai } \\ \text { "Wilayah }\end{array}$
obyek/subyek yang mempunyai
kualitas dan karakteristik tertentu
yang ditetapkan oleh penelitian
untuk dipelajari dan kemudian
ditarik kesimpulan". Berdasarkan
pengertian di atas, populasi
merupakan obyek atau subyek
yang berada pada suatu wilayah
dan memenuhi syarat tertentu
yang berkaitan dengan masalah
dalam penelitian. Poulasi dalam
penelitian ini adalah karyawan
yang bekerja di PT Gada


Rajawali Dunia dengan jumlah karyawan, dari bulan Mei sampai bulan Juli tahun 2017

\section{F. Teknik Analisi Data}

Analisis data Analisis data yang digunakan dalam penelitian ini adalah uji validitas dan uji reliabilitas. Pengujian validitas menggunakan rumus korelasi pearson product moment, dengan Syarat uji validitas jika menggunakan SPSS adalah Correlated ini Menurut Sugiyono, (2013:182) kalau Uji Validitas pakai $r$ tabel 0,3 yaitu: Jika $r \leq 0,3$, Maka dinyatakan gugur / Tidak di valid dan Jika $r$ $\geq 0,3$, Maka dinyatakan Pearson Correlation. Serta pengujian karyawan sebanyak 42 reliabilitas dalam penelitian ini menggunakan nilai Alpha Coanbach dengan kriteria uji reliabilitas dalam penelitian ini, Kriteria uji reliabilitas dalam penelitian ini menurut Sugiyono (2013:184) adalah 0,6 dimana Jika $r_{\text {ca }} \leq 0,6$ maka butir instrument dinyatakan tidak reliabel dan Jika $\mathrm{r}_{\text {ca }} \geq 0.6$ maka butir sinstrument dinyatakan reliabel. Teknik analsis data antara lain uji asumsi klasik dan analisis regresi ganda. uji asumsi klasik terdiri dari uji normalitas, uji multikolinearitas, dan uji heteroskedastisitas.

\section{HASIL PENELITIAN}

\section{A. Analisis Deskriptif}

1. Vairbael Kepemimpinan

Tabel 4.1

Deskripsi Variabel Kepemimpinan

\begin{tabular}{|l|l|c|c|c|c|c|c|c|}
\hline N0 & Pertanyaan & SS & S & RR & TS & STS & Skor & Rata-rata \\
\hline 1 & $\begin{array}{l}\text { Atasan saya selalu mengarahkan } \\
\text { pekerjaan sesuaidengan tujuan dan } \\
\text { menjelaskan dengan baik }\end{array}$ & 40 & 124 & 6 & 2 & 0 & 172 & 4,10 \\
\hline 2 & $\begin{array}{l}\text { Atasan yang selalu memotivasi saya } \\
\text { didalam menyelesaikan pekerjaan } \\
\text { dengan baik }\end{array}$ & 30 & 120 & 18 & 0 & 0 & 168 & 4,00 \\
\hline 3 & $\begin{array}{l}\text { Dapat membantu menyelesaiakan } \\
\text { pekerjaan karyawanya }\end{array}$ & 70 & 108 & 3 & 0 & 0 & 181 & 4,31 \\
\hline 4 & $\begin{array}{l}\text { Atasan saya selalu hadirtepatwaktu } \\
\text { dan bahkan sebelum saya dating }\end{array}$ & 30 & 108 & 27 & 0 & 0 & 165 & 3,93 \\
\hline 5 & $\begin{array}{l}\text { Pemimpin selalu melibatkan } \\
\text { bawahanya didalam mengambi } \\
\text { keputusan terutama berkaitan } \\
\text { dengan pekerjaan }\end{array}$ & 90 & 88 & 6 & 0 & 0 & 184 & 4,38 \\
\hline 6 & $\begin{array}{l}\text { Atasan saya dapat membantu saya } \\
\text { untuk menyelesaikan masalah yang } \\
\text { berkaitan dengan pekerjaan yang } \\
\text { dijalani }\end{array}$ & 75 & 96 & 9 & 0 & 0 & 180 & 4,29 \\
\hline 7 & $\begin{array}{l}\text { Atasan saya selalu memberikan } \\
\text { arahan sesuai dengan pengalaman } \\
\text { kerja yang pernah dialaminya }\end{array}$ & 105 & 64 & 15 & 0 & 0 & 184 & 4,38 \\
\hline 8 & $\begin{array}{l}\text { Terdakang pemimpin membantu } \\
\text { bawahan untuk dapat } \\
\text { menyelesaikan pekerjaa agar tepat } \\
\text { waktu }\end{array}$ & 95 & 60 & 18 & 4 & 0 & 177 & 4,21 \\
\hline 9 & $\begin{array}{l}\text { Pempimpin mengarahkan kami } \\
\text { untuk dapat menyelesaikan tugas } \\
\text { yang pribadidan kerjasama }\end{array}$ & 95 & 52 & 30 & 0 & 0 & 177 & 4,21 \\
\hline 10 & $\begin{array}{l}\text { Pemimpin selalu memberikan } \\
\text { arahan untuk dapat mengembil } \\
\text { keputusan dalam menyelesaikan } \\
\text { pekerjaan }\end{array}$ & 170 & 28 & 0 & 2 & 0 & 200 & 4,76 \\
\hline Jumlah & 800 & 848 & 132 & 8 & 0 & 1788 & 42,57 \\
\hline Presentase & 19,05 & 20,19 & 3,14 & 0,19 & 0,00 & 42,57 & 4,26 \\
\hline
\end{tabular}

Sumber: Hasil Olah Data 
Berdasarkan data tabel di atas, rata-rata skor kepemimpinan sebesar 4,26 masuk pada interval 4,20 - 5,00 dengan interprestasi Sangat Baik artinya karyawaan mempunyai persepsi yang Sangat Baik terhadap atasan mereke. Dan hal ini di buktikan dari jawaban karyawan dari Skor tertinggi yaitu 4,76 pada pernyataan " Pemimpin selalu memberikan arahan untuk dapat mengembil keputusan dalam menyelesaikan pekerjaan "dimana pemimpin selalu meberikan araha untuk dapat mengambil keputusan dalam menyelesaikan pekerjaan dengan baik, namun di sisi lain pihak perusahaan harus lebih meningkatkan kepemimpinan atau atasan karena masih terdapat skor rendah yaitu 3,93 pada pernyataan " Atasan saya selalu hadir tepat waktu dan bahkan sebelum saya datang" dimana dari hasi obervasi atasan terkadang datang tidak tepat waktu, maka dari itu atasan yang datang tidak tepat waktu juga harus mendapatkan sangsi agar dapat memberikan contoh yang baik kepada bawahanya.

\section{Variabel Kinerja}

Tabel 4.2

Deskripsi Variabel Kinerja

\begin{tabular}{|c|c|c|c|c|c|c|c|c|}
\hline No & Pertanyaan & SS & $\mathrm{S}$ & RR & TS & STS & Skor & Rata-rata \\
\hline 1 & $\begin{array}{l}\begin{array}{l}\text { Saya menyelesaikan tugas dengan } \\
\text { baik dan teliti }\end{array} \\
\end{array}$ & 80 & 104 & 0 & 0 & 0 & 184 & 4,38 \\
\hline 2 & $\begin{array}{l}\text { Saya dapat menyelesaiakan } \\
\text { pekerjaan seusai dengan waktu yang } \\
\text { telat ditetapkan }\end{array}$ & 115 & 60 & 6 & 4 & 0 & 185 & 4,40 \\
\hline 3 & $\begin{array}{l}\text { Pekerjaan yang diperintah dapat } \\
\text { saya selesaikan sebelum waktu nya }\end{array}$ & 165 & 32 & 0 & 2 & 0 & 199 & 4,74 \\
\hline 4 & $\begin{array}{l}\text { Saya dapat menyelesaikan masalah } \\
\text { yang berkaitan dengan pekerjaan } \\
\text { yang saya jalani }\end{array}$ & 115 & 68 & 3 & 2 & 0 & 188 & 4,48 \\
\hline 5 & $\begin{array}{l}\text { Saya berusaha memusyawarahkan } \\
\text { pekerjaan yang saya jalani jika } \\
\text { terjadikesulitan }\end{array}$ & 30 & 120 & 18 & 0 & 0 & 168 & 4,00 \\
\hline 6 & $\begin{array}{l}\text { Pempimpin saya selalu memberikan } \\
\text { motivasi kepada saya }\end{array}$ & 95 & 60 & 18 & 4 & 0 & 177 & 4,21 \\
\hline 7 & $\begin{array}{l}\text { Saya berusaha menjalin komunikasi } \\
\text { dan beruhubungan dengan teman } \\
\text { satu divisi }\end{array}$ & 135 & 48 & 9 & 0 & 0 & 192 & 4,57 \\
\hline 8 & $\begin{array}{ll}\begin{array}{l}\text { Saya dapat } \\
\text { pekerjaan tanpa } \\
\text { atasan saya }\end{array} & \begin{array}{l}\text { menyelesaiakan } \\
\text { perintah dari }\end{array} \\
\end{array}$ & 90 & 88 & 6 & 0 & 0 & 184 & 4,38 \\
\hline 9 & $\begin{array}{l}\text { Terkadang saya member masukan } \\
\text { saran kepada teman jika mengalami } \\
\text { kesulitasn dalam menyelesaikan } \\
\text { pekerjaan }\end{array}$ & 75 & 96 & 9 & 0 & 0 & 180 & 4,29 \\
\hline 10 & $\begin{array}{l}\text { Terkadang saya menggunakan cara } \\
\text { baru untuk menyelesaikan pekerjaa } \\
\text { agar tidak jenuh }\end{array}$ & 50 & 64 & 45 & 2 & 0 & 161 & 3,83 \\
\hline \multicolumn{2}{|c|}{ Jumlah } & 950 & 740 & 114 & 14 & 0 & 1818 & 43,29 \\
\hline \multicolumn{2}{|c|}{ Presentase } & 22,62 & 17,62 & 2,71 & 0,33 & 0,00 & 43,29 & 4,33 \\
\hline
\end{tabular}

\section{Sumber: Hasil Olah Data}

Berdasarkan data tabel di atas, ratarata skor kinerja sebesar 4,33 masuk pada interval 4,20 - 5,00 dengan interprestasi Sangat Baik artinya karyawan mempunya kinerja yang Baik. Dan hal ini di buktikan dari jawaban karyawan dari Skor tertinggi yaitu 4,74 pada pernyataan "Pekerjaan yang diperintah dapat saya selesaikan sebelum waktu nya" dimana karyawan rata-rata dapat menyelesaikan pekerjan sebelum waktu atau tepat sesuai waktu yang ditentukan hal ini mendakan 
bahwa kinerja karyawan sudah baik, namun di sisi lain karyawan harus dapat meningkatkan kinerja, karena masih terdapat skor rendah yaitu 3,83 pada pernyataan" Terkadang saya menggunakan cara baru untuk menyelesaikan pekerjaa agar tidak jenuh" maka dari itu sebaiknya karyawan dapat menggunakan metode baru atau melakukan inovasi terhadap pekerjaanya dengan merubah cara kerjanya agar lebih baik lagi sehinggan tidak merasa jenuh dengan pekerjaan yang di lakukannya sehari-hari.

\section{Variabel Kepuasan Kerja}

Tabel 4.3

Deskripsi Variabel Kepuasan Kerja

\begin{tabular}{|c|c|c|c|c|c|c|c|c|}
\hline No & Pertanyasn & SS & S & RR & TS & STS & Slcor & Rata-rata \\
\hline 1 & $\begin{array}{l}\text { Saya dapat menyelesailcan } \\
\text { masalah yang saya } \\
\text { hadapai yidalam } \\
\text { pelkerjasn dengan baik }\end{array}$ & 60 & 64 & 36 & 2 & 1 & 163 & 3,88 \\
\hline 2 & $\begin{array}{l}\text { Dengan belkerja di } \\
\text { perusahan ini saya dapat } \\
\text { memenuhi lkebutuuhan } \\
\text { says }\end{array}$ & 95 & 80 & 9 & 0 & 0 & 184 & 4,38 \\
\hline 3 & $\begin{array}{l}\text { Saya mendapatcan gaji } \\
\text { yang sesuai dengan beban } \\
\text { kerja yang saya jalani }\end{array}$ & 35 & 72 & 21 & 12 & 4 & 144 & 3,43 \\
\hline 4 & 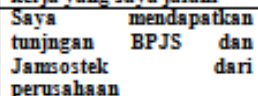 & 75 & 88 & 9 & 2 & 1 & 175 & 4,17 \\
\hline 5 & $\begin{array}{l}\text { Saya merasa bangga jilca } \\
\text { dapat menyelesaikan } \\
\text { pelkerjasn dengan baik } \\
\text { dan sesuai target }\end{array}$ & 15 & 60 & 36 & 8 & 8 & 127 & 3,02 \\
\hline 6 & $\begin{array}{l}\text { Saya mendapatcan } \\
\text { penghargasn atas hasil } \\
\text { kerja saya dari atasan } \\
\text { saya }\end{array}$ & 20 & 88 & 21 & 6 & 6 & 141 & 3,36 \\
\hline 7 & $\begin{array}{l}\text { Saya alcan dipromosilcan } \\
\text { untul naik jabatan jilca } \\
\text { menilili lainerja yang } \\
\text { baik }\end{array}$ & 45 & 80 & 36 & 2 & 0 & 163 & 3,88 \\
\hline 8 & $\begin{array}{|lrr|}\text { Saya } & \text { mendapatcan } \\
\text { pelatihan yang } & \text { sama } \\
\text { dengan dengan } & \text { relcan } \\
\text { lkerja seteamsaya } & \\
\end{array}$ & 40 & 72 & 33 & 8 & 1 & 154 & 3,67 \\
\hline 9 & $\begin{array}{l}\text { Saya sensing jilca } \\
\text { memilili team kerja yang } \\
\text { mudah dan dapat diajal } \\
\text { bekcerja sama }\end{array}$ & 60 & 64 & 36 & 2 & 1 & 163 & 3,88 \\
\hline 10 & $\begin{array}{l}\text { Saya percaya dengan } \\
\text { belkerja diperusahasn ini } \\
\text { saya dapat memenuhi } \\
\text { kcebutuhan saya }\end{array}$ & 45 & 64 & 48 & 2 & 0 & 159 & 3,79 \\
\hline \multicolumn{2}{|c|}{ Jumlah } & 490 & 732 & 285 & 44 & 22 & 1573 & 37,45 \\
\hline \multicolumn{2}{|c|}{ Presentase } & 11,67 & 17,43 & 6,79 & 1,05 & 0,52 & 37,45 & 3,75 \\
\hline
\end{tabular}

\section{Sumber: Hasil Olah Data}

Berdasarkan data tabel di atas, rata-rata skor kepuasan kerja sebesar 3,75 masuk pada interval 3,40 - 4,19 dengan inter prestasi Baik artinya mayoritas karyawan merasa puas dengan pekerjaan yang dijalani nya hal ini di buktikan dari jawaban karyawan dari Skor tertinggi yaitu 4,38 pada pernyataan "Dengan bekerja di perusahan ini saya dapat memenuhi kebutuuhan saya" dimana mayoritas yang bekerja diperusahaan ini dapat memenuhi kebutuhanya dari Gaji yang diterima, baik untuk Kebutuha primer ataupun skundernya, namun di samping itu masih terdapat karyawan yang merasa tidak puas dengan pekerjaan yang dijalani karena 
masih terdpaat skor rendah yaitu 3,02 pada pernyataan "Saya merasa bangga jika dapat menyelesaikan pekerjaan dengan baik dan sesuai target" dimana hasil observasi diperoleh masih ada karyawan yang tidak dapat menyelesaikan pekerjaan sesuai dengan target yang ditentukaan, maka dari itu sebaiknya pemimpin dapat memberikan masukan lebih baik lagi kepada karyawanya agar dapat menyelesaikan pekerjaan sesuai dengan tujuan dan memberikan sangsi jika masih terdapat karyawan yang tidak menyelesaikan pekerjaan tepat pada waktunya.

\section{B. Hasil Uji Kualitas Data Data}

1. Uji Validitas

Pada program SPSS teknik pengujian yang digunakan oleh peneliti untuk uji validitas adalah menggunakan korelasi Bivariate Pearson dengan taraf signifikasi 0,05. Dan $r$ tabael $0, \quad 30$ dengan mengunaka teori dari Sugiyono (2013:182). Dimana hasil nya dpaat dilihat pada tabel berikut

Tabel 4.1

Rangkuman Uji Validitas

\begin{tabular}{|c|c|c|c|}
\hline $\begin{array}{c}\mathrm{N} \\
\mathrm{o}\end{array}$ & $\begin{array}{c}\mathrm{R} \\
\text { hitung }\end{array}$ & $\begin{array}{c}\mathrm{R} \\
\text { tabel }\end{array}$ & Kep \\
\hline \multicolumn{4}{|c|}{ Variabel } \\
Kepemimpinan $(\mathrm{X})$ \\
\hline 1 & 0,59 & 0,3 & Val \\
& 5 & 00 & $\mathrm{id}$ \\
\hline 2 & 0,49 & 0,3 & Val \\
& 3 & 00 & id \\
\hline
\end{tabular}

\begin{tabular}{|c|c|c|c|}
\hline 3 & $\begin{array}{c}0,41 \\
0\end{array}$ & $\begin{array}{c}0,3 \\
00\end{array}$ & $\begin{array}{l}\text { Val } \\
\text { id }\end{array}$ \\
\hline 4 & $\begin{array}{c}0,35 \\
4\end{array}$ & $\begin{array}{l}0,3 \\
00\end{array}$ & $\begin{array}{l}\text { Val } \\
\text { id }\end{array}$ \\
\hline 5 & $\begin{array}{c}0,50 \\
1\end{array}$ & $\begin{array}{c}0,3 \\
00\end{array}$ & $\begin{array}{l}\text { Val } \\
\text { id }\end{array}$ \\
\hline 6 & $\begin{array}{c}0,74 \\
4\end{array}$ & $\begin{array}{c}0,3 \\
00\end{array}$ & $\begin{array}{l}\text { Val } \\
\text { id }\end{array}$ \\
\hline 7 & $\begin{array}{c}0,76 \\
4\end{array}$ & $\begin{array}{c}0,3 \\
00\end{array}$ & $\begin{array}{l}\text { Val } \\
\text { id }\end{array}$ \\
\hline 8 & $\begin{array}{c}0,80 \\
6\end{array}$ & $\begin{array}{c}0,3 \\
00\end{array}$ & $\begin{array}{l}\text { Val } \\
\text { id }\end{array}$ \\
\hline 9 & $\begin{array}{c}0,63 \\
9\end{array}$ & $\begin{array}{c}0,3 \\
00\end{array}$ & $\begin{array}{l}\text { Val } \\
\text { id }\end{array}$ \\
\hline $\begin{array}{l}1 \\
0\end{array}$ & $\begin{array}{c}0,39 \\
2\end{array}$ & $\begin{array}{c}0,3 \\
00\end{array}$ & $\begin{array}{l}\text { Val } \\
\text { id }\end{array}$ \\
\hline & iabel & inerja & (Y1) \\
\hline 1 & $\begin{array}{c}0,57 \\
9\end{array}$ & $\begin{array}{c}0,3 \\
00\end{array}$ & $\begin{array}{l}\text { Val } \\
\text { id }\end{array}$ \\
\hline 2 & $\begin{array}{c}0,49 \\
2\end{array}$ & $\begin{array}{c}0,3 \\
00\end{array}$ & $\begin{array}{l}\text { Val } \\
\text { id }\end{array}$ \\
\hline 3 & $\begin{array}{c}0,57 \\
5\end{array}$ & $\begin{array}{c}0,3 \\
00\end{array}$ & $\begin{array}{l}\text { Val } \\
\text { id }\end{array}$ \\
\hline 4 & $\begin{array}{c}0,68 \\
9\end{array}$ & $\begin{array}{c}0,3 \\
00 \\
\end{array}$ & $\begin{array}{l}\text { Val } \\
\text { id }\end{array}$ \\
\hline 5 & $\begin{array}{c}0,41 \\
9\end{array}$ & $\begin{array}{c}0,3 \\
00\end{array}$ & $\begin{array}{l}\text { Val } \\
\text { id }\end{array}$ \\
\hline 6 & $\begin{array}{c}0,70 \\
6\end{array}$ & $\begin{array}{c}0,3 \\
00\end{array}$ & $\begin{array}{l}\text { Val } \\
\text { id }\end{array}$ \\
\hline 7 & $\begin{array}{c}0,44 \\
9\end{array}$ & $\begin{array}{c}0,3 \\
00 \\
\end{array}$ & $\begin{array}{l}\text { Val } \\
\text { id }\end{array}$ \\
\hline 8 & $\begin{array}{c}0,37 \\
1\end{array}$ & $\begin{array}{c}0,3 \\
00\end{array}$ & $\begin{array}{l}\text { Val } \\
\text { id }\end{array}$ \\
\hline 9 & $\begin{array}{c}0,57 \\
1\end{array}$ & $\begin{array}{c}0,3 \\
00\end{array}$ & $\begin{array}{l}\text { Val } \\
\text { id }\end{array}$ \\
\hline $\begin{array}{l}1 \\
0\end{array}$ & $\begin{array}{c}0,47 \\
5\end{array}$ & $\begin{array}{c}0,3 \\
00\end{array}$ & $\begin{array}{l}\text { Val } \\
\text { id }\end{array}$ \\
\hline \multicolumn{4}{|c|}{$\begin{array}{l}\text { Variabel Kepuasan } \\
\text { Kerja (Y2) }\end{array}$} \\
\hline 1 & $\begin{array}{c}0,76 \\
0\end{array}$ & $\begin{array}{c}0,3 \\
00\end{array}$ & $\begin{array}{l}\text { Val } \\
\text { id }\end{array}$ \\
\hline 2 & $\begin{array}{c}0,44 \\
3\end{array}$ & $\begin{array}{c}0,3 \\
00\end{array}$ & $\begin{array}{l}\text { Val } \\
\text { id }\end{array}$ \\
\hline 3 & $\begin{array}{c}0,64 \\
3\end{array}$ & $\begin{array}{c}0,3 \\
00\end{array}$ & $\begin{array}{l}\text { Val } \\
\text { id }\end{array}$ \\
\hline
\end{tabular}




\begin{tabular}{|c|c|c|c|}
\hline 4 & $\begin{array}{c}0,66 \\
5\end{array}$ & $\begin{array}{c}0,3 \\
00\end{array}$ & $\begin{array}{c}\text { Val } \\
\text { id }\end{array}$ \\
\hline 5 & $\begin{array}{c}0,75 \\
6\end{array}$ & $\begin{array}{c}0,3 \\
00\end{array}$ & $\begin{array}{c}\text { Val } \\
\text { id }\end{array}$ \\
\hline 6 & $\begin{array}{c}0,75 \\
5\end{array}$ & $\begin{array}{c}0,3 \\
00\end{array}$ & $\begin{array}{c}\text { Val } \\
\text { id }\end{array}$ \\
\hline 7 & $\begin{array}{c}0,74 \\
7\end{array}$ & $\begin{array}{c}0,3 \\
00\end{array}$ & $\begin{array}{c}\text { Val } \\
\text { id }\end{array}$ \\
\hline 8 & $\begin{array}{c}0,77 \\
5\end{array}$ & $\begin{array}{c}0,3 \\
00\end{array}$ & $\begin{array}{c}\text { Val } \\
\text { id }\end{array}$ \\
\hline 9 & $\begin{array}{c}0,76 \\
0\end{array}$ & $\begin{array}{c}0,3 \\
00\end{array}$ & $\begin{array}{c}\text { Val } \\
\text { id }\end{array}$ \\
\hline 1 & 0,67 & 0,3 & Val \\
0 & 7 & 00 & id \\
\hline
\end{tabular}

Sumber: Hasil Olah Data

2. Uji Reliabilitas

Pengujian reliabilitas pada penelitian ini dilakukan dengan menggunakan metode Alpha-Cronbach dengan menggunakan aplikasi SPSS 22. Setelah dilakukan pengujian menggunakan SPSS 22 maka didapatkan hasilnya sebagai berikut :

Tabel 4.2

Hasil Uji Reliabilitas

\begin{tabular}{|c|c|c|c|}
\hline No & $\mathrm{R}_{\mathrm{ca}}$ & $\mathrm{R}_{\text {tabel }}$ & Kep \\
\hline \multicolumn{4}{|c|}{ Kepemimpinan $(\mathrm{X})$} \\
\hline- & 0,780 & 0,60 & Valid \\
\hline \multicolumn{4}{|c|}{ Kinerja $\left(\mathrm{Y}_{1}\right)$} \\
\hline- & 0,715 & 0,60 & Valid \\
\hline \multicolumn{4}{|c|}{ Kepuasan Kerja $\left(\mathrm{Y}_{2}\right)$} \\
\hline- & 0,880 & 0,60 & Valid \\
\hline
\end{tabular}

Sumber: Hasil Olah Data

\section{Analisis Data}

1. Regresi Linear Sederhana dan Hipotesis

a. Analisis Regresi Lienar Sederhana dan Uji Hipotesis Variabel
Kepempinan Terhadap Kinerja Karyawan.

Tabel 4.3

Hasil Uji Regresi Linear

Serdegohana X-y1

\begin{tabular}{|c|c|c|c|c|c|c|}
\hline \multirow[b]{2}{*}{ Model } & & \multicolumn{2}{|c|}{ Unstandardized Coefficients } & \multirow{2}{*}{$\begin{array}{c}\begin{array}{c}\text { Standardized } \\
\text { Coefficients }\end{array} \\
\text { Beta }\end{array}$} & \multirow[b]{2}{*}{$t$} & \multirow[b]{2}{*}{ Sig. } \\
\hline & & B & Std. Error & & & \\
\hline \multirow[t]{2}{*}{1} & (Constant) & 13.800 & 4.361 & & 3.164 & .003 \\
\hline & Kepemimpinan & 693 & .102 & .732 & 6.786 & .000 \\
\hline
\end{tabular}

Sumber: Hasil Olah Data

Dari tabel tersebut diperoleh persamaan regresi linier sederhana sebagai berikut:

$$
\mathrm{Y}_{1}=13,800+0,693
$$

Dimana:

$\mathrm{a}=13,800$ merupakan nilai konstanta, jika kepemimpinan dianggap tidak ada maka nilai kinerja karyawan sebesar 13,800

$\mathrm{b}_{1}=0,693$ koefisien regresi variabel kepimpinan sebesar 0,693 artinya jika kepemimpinan mengalami peningkatan satu-satuan maka kinerja karyawan mengalami peningkatan sebesar 0,693 dan koefisein regresi bernilai positif artinya terjadi hubungan positif antara kepimimpinan dan kinerja karyawan dimana semakin baik pemimpin maka akan semakin baik juga kinerja karyawan.

Berdasarkan tabel tersebut maka dapat dilihat nilai $\mathrm{t}$ hitung $>\mathrm{t}$ tabel dan nilai sig $\langle 0,05$ sehingga $6,786>$ 2,021 dan $0,000<0,05$ maka $\mathrm{Ha}_{1}$ diterima dan $\mathrm{Ho}_{1}$ ditolak.

b. Analisis Regresi Lienar Sederhana dan Uji Hipotesis Variabel Kepempinan Terhadap Kepuasan Kerja 
Tabel 4.4

Hasil Uji Regresi Linear

Serderhana X-y 2

Coefficients $^{\mathrm{a}}$

\begin{tabular}{|c|c|c|c|c|c|c|}
\hline \multirow[b]{2}{*}{ Model } & & \multicolumn{2}{|c|}{ Unstandardized Coefficients } & \multirow{2}{*}{$\begin{array}{c}\text { Standardized } \\
\text { Coefficients } \\
\text { Beta } \\
\end{array}$} & \multirow[b]{2}{*}{$t$} & \multirow[b]{2}{*}{ Sig. } \\
\hline & & B & Std. Error & & & \\
\hline \multirow[t]{2}{*}{1} & (Constant) & 27.026 & 12.118 & & 2.230 & .000 \\
\hline & Kepemimpinan & .245 & .284 & .135 & 4.864 & .003 \\
\hline
\end{tabular}

a. Dependent Variable: Kepuasan Kerja

Sumber: Hasil Olah Data

Dari tabel tersebut diperoleh persamaan regresi linier sederhana sebagai berikut:

$$
Y_{2}=27,026+0,245
$$

Dimana:

$\mathrm{a}=27,026$ merupakan nilai konstanta, jika kepemimpinan dianggap tidak ada maka nilai kepuasan sebesar 27,026

$\mathrm{b}_{2}=0,245$ koefisien regresi variabel kepimpinan sebesar 0,245 artinya jika kepemimpinan mengalami peningkatan satu-satuan maka kepuasan kerja mengalami peningkatan sebesar 0,245 dan koefisein regresi bernilai positif artinya terjadi hubungan positif antara kepimimpinan dan kepuasan kerja dimana semakin baik pemimpin maka semakin puas karyawan terhadap kepemimpinan.

Berdasarkan

tabel tersebut maka dapat dilihat nilai $\mathrm{t}_{\text {hitung }}>\mathrm{t}$ tabel dan nilai sig $\langle 0,05$ sehingga 4,864 > 2,021 dan $0,003<0,05$ maka $\mathrm{Ha}_{2}$ diterima dan $\mathrm{Ho}_{2}$ ditolak.

c. Analisis Regresi Lienar Sederhana dan Uji Hipotesis Variabel Kinerja Karyawan Terhadap Kepuasan Kerja
Tabel 4.5

Hasil Uji Regresi Linear

Serderhana y1-y2

Coefficients $^{\mathrm{a}}$

\begin{tabular}{|c|c|c|c|c|c|c|}
\hline \multirow[b]{2}{*}{ Model } & & \multicolumn{2}{|c|}{ Unstandardized Coefficients } & \multirow{2}{*}{$\begin{array}{c}\begin{array}{c}\text { Standardized } \\
\text { Coefficients }\end{array} \\
\text { Beta }\end{array}$} & \multirow[b]{2}{*}{$t$} & \multirow[b]{2}{*}{ Sig. } \\
\hline & & $\mathrm{B}$ & Std. Error & & & \\
\hline & (Constant) & 36.650 & 13.128 & & 2.792 & .008 \\
\hline & Kinerja Karyawan & .219 & .302 & .010 & 2.613 & .001 \\
\hline
\end{tabular}

a. Dependent Variable: Kepuasan Kerja

Sumber: Hasil Olah Data

Dari tabel tersebut diperoleh persamaan regresi linier sederhana sebagai berikut:

$\mathrm{Y}_{1}=36,650+0,219$

Dimana:

$\mathrm{a}=36,650$ merupakan nilai konstanta, jika kinerja karyawan dianggap tidak ada maka nilai kepuasan sebesar 36,650

$\mathrm{b}_{1}=0,219 \quad$ koefisien regresi variabel kinerja karyawan sebesar 0,219 artinya jika kinerja karyawan mengalami peningkatan satu-satuan maka kepuasan kerja mengalami peningkatan sebesar 0,219 dan koefisein regresi bernilai positif artinya terjadi hubungan positif antara kinerja karyawan dan kepuasan kerja dimana semakin baik kinerja karyawan maka semakin puas karyawan terhadap hasil kerja yang diperoleh nya.

Berdasarkan tabel tersebut maka dapat dilihat nilai $\mathrm{t}$ hitung $>\mathrm{t}$ tabel dan nilai sig $<0,05$ sehingga $2,613>2,021$ 
dan $0,001<0,05$ maka $\mathrm{Ha}_{3}$ diterima dan $\mathrm{Ho}_{3}$ ditolak.

2. Koefisien Determinasi

a. Koefisien Determinasi Variabel Kepempinan Terhadap Kinerja Karyawan

Tabel 4.6

Hasil Koefisien Determinasi X-y Model Summary

\begin{tabular}{|c|c|r|r|r|}
\hline Model & $\mathrm{R}$ & R Square & $\begin{array}{c}\text { Adjusted R } \\
\text { Square }\end{array}$ & $\begin{array}{c}\text { Std. Error of } \\
\text { the Estimate }\end{array}$ \\
\hline 1 & $.732^{\mathrm{a}}$ & .535 & .524 & 2.450 \\
\hline
\end{tabular}

a. Predictors: (Constant), Kepemimpinan

Sumber: Hasil Olah Data

Berdasarkan tabel diatas maka dapat diketahui nilai $r$ square adalah 0,535 hal ini berarti kepemimpinan mempunyai kontribusi secara bersama-sama sebesar $53,5 \%$ terhadap variabel kinerja karyawan. Sisanya $46,5 \%$ dipengaruh oleh factor lain yang tidak diteliti dalam penelitian ini.

$\begin{array}{lr}\text { b. Koefisien } & \text { Determinasi } \\ \text { Variabel } & \text { Kepempinan } \\ \text { Terhadap } & \text { Kepuasan } \\ \text { Kerja } & \end{array}$

Tabel 4.7

Hasil Koefisien Determinasi X-y Model Summary

\begin{tabular}{|c|l|r|r|r|}
\hline Model & $\mathrm{R}$ & R Square & $\begin{array}{c}\text { Adjusted R } \\
\text { Square }\end{array}$ & $\begin{array}{c}\text { Std. Error of } \\
\text { the Estimate }\end{array}$ \\
\hline 1 & $.653^{\mathrm{a}}$ & .426 & .437 & 7.308 \\
\hline
\end{tabular}

a. Predictors: (Constant), Kepemimpinan

Sumber: Hasil Olah Data

Berdasarkan tabel diatas maka dapat diketahui nilai $r$ square adalah 0,426 hal ini berarti kepemimpinan mempunyai kontribusi secara bersama-sama sebesar $\quad 42,6 \%$ terhadap variabel kepuasan kerja. Sisanya 53,5\% dipengaruh oleh factor lain yang tidak diteliti dalam penelitian ini.

$$
\begin{array}{lr}
\text { c. Koefisien } & \text { Determinasi } \\
\text { Variabel } & \text { Kinerja } \\
\text { Karyawan } & \text { Terhadap } \\
\text { Kepuasan Kerja. }
\end{array}
$$

Tabel 4.8

Hasil Koefisien Determinasi $\mathbf{y}_{1}-\mathbf{y}_{2}$ Model Summary

\begin{tabular}{|c|c|r|r|r|}
\hline Model & $\mathrm{R}$ & R Square & $\begin{array}{c}\text { Adjusted R } \\
\text { Square }\end{array}$ & $\begin{array}{c}\text { Std. Error of } \\
\text { the Estimate }\end{array}$ \\
\hline 1 & $.651^{\mathrm{a}}$ & .424 & .435 & 6.871 \\
\hline
\end{tabular}

a. Predictors: (Constant), Kinerja Karyawan

\section{Sumber: Hasil Olah Data}

Berdasarkan tabel diatas maka dapat diketahui nilai $r$ square adalah 0,424 hal ini berarti kinerja karyawan mempunyai kontribusi sebesar $42,4 \%$ terhadap variabel kepuasan kerja. Sisanya 57,6\% dipengaruh oleh factor lain yang tidak diteliti dalam penelitian ini.

\section{Pembahasan}

$\mathrm{X}-\mathrm{Y}_{1}$ Kepemimpinan- Kinerja

Dari hasil analisis deskripsi diperoleh rata-rata skor kepemimpinan sebesar 4,26 masuk pada interval 4,20 - 5,00 dengan interprestasi Sangat Baik artinya karyawaan mempunyai persepsi yang sangat baik terhadap atasan mereka.

Dari hasil uji validitas istrumen kuisioner no 1 diperoleh nilai $r_{\text {hitung }}>$ $\mathrm{r}_{\text {tabel }}$ dimana 0,595>0,300 dan untuk instrument no 2-10 pun dinyatakan valid.

Dari hasil uji reliabilitas diperoleh nilai $\mathrm{R}_{\mathrm{ca}} 0,780$ sehingga $0,780>0,600$ maka kuisioner varariabel kepemimpinan dinyatakan reliabel

$\mathrm{Y}_{1}=13,800+0,693$ Dimana: $\mathrm{a}=$ 13,800 merupakan nilai konstanta, jika kepemimpinan dianggap tidak 
ada maka nilai kinerja karyawan sebesar 13,800 dan $b_{1}=0,693$ koefisien regresi variabel kepimpinan sebesar 0,693 artinya jika kepemimpinan mengalami peningkatan satu-satuan maka kinerja karyawan mengalami peningkatan sebesar 0,693 dan koefisein regresi bernilai positif artinya terjadi hubungan positif antara kepimimpinan dan kinerja karyawan dimana semakin baik pemimpin maka akan semakin baik juga kinerja karyawan.

Berdasarkan tabel tersebut maka dapat dilihat nilai $\mathrm{t}$ hitung $>\mathrm{t}$ tabel dan nilai sig $<0,05$ sehingga 6,786 > 2,021 dan $0,000<0,05$ maka $\mathrm{Ha}_{1}$ diterima dan $\mathrm{Ho}_{1}$ ditolak. Hal ini sejalan dengan penelitian yang dilakukan oleh Rommy, dkk (2016), I Nyoman, dkk (2016) dan Akmad, dkk (2016).

Berdasarkan tabel summary maka dapat diketahui nilai $r$ square adalah 0,535 hal ini berarti kepemimpinan mempunyai kontribusi secara bersama-sama sebesar $53,5 \%$ terhadap variabel kinerja karyawan. Sisanya $46,5 \%$ dipengaruh oleh factor lain yang tidak diteliti dalam penelitian ini.

\section{$\mathrm{X}-\mathrm{Y}_{2} \quad$ Kepemimpinan - Kepuasan Kerja}

Dari hasil analisis deskripsi, rata-rata skor kinerja sebesar 4,33 masuk pada interval 4,20 - 5,00 dengan interprestasi Sangat Baik artinya karyawan mempunya kinerja yang Baik.

Dari hasil uji validitas istrumen kuisioner no 1 diperoleh nilai $\mathrm{r}_{\text {hitung }}>$ $r_{\text {tabel }}$ dimana 0,579>0,300 dan untuk instrument no 2-10 pun dinyatakan valid.
Dari hasil uji reliabilitas diperoleh nilai $R_{c a} 0,715$ sehingga $0,715>0,600$ maka kuisioner varariabel kinerja karyawan dinyatakan reliabel

$\mathrm{Y}_{2}=27,026+0,245 \quad$ Dimana: $\mathrm{a}=$ 27,026 merupakan nilai konstanta, jika kepemimpinan dianggap tidak ada maka nilai kepuasan kerja sebesar 27,026 dan $b_{2}=0,245$ koefisien regresi variabel kepimpinan sebesar 0,245 artinya jika kepemimpinan mengalami peningkatan satu-satuan maka kepuasan kerja mengalami peningkatan sebesar 0,245 dan koefisein regresi bernilai positif artinya terjadi hubungan positif antara kepimimpinan dan kepuasan kerja dimana semakin baik pemimpin maka semakin puas karyawan terhadap kepemimpinan.

Berdasarkan tabel tersebut maka dapat dilihat nilai $\mathrm{t}$ hitung $>\mathrm{t}$ tabel dan nilai sig $<0,05$ sehingga 4,864 > 2,021 dan $0,003<0,05$ maka $\mathrm{Ha}_{2}$ diterima dan $\mathrm{Ho}_{2}$ ditolak. Hal iji sejalan dengan penelitian dari Kadek (2017), Ferry (2017), Unna (2017).

Berdasarkan tabel summary maka dapat diketahui nilai $r$ square adalah 0,426 hal ini berarti kepemimpinan mempunyai kontribusi secara bersama-sama sebesar $\quad 42,6 \%$ terhadap variabel kepuasan kerja. Sisanya $53,5 \%$ dipengaruh oleh factor lain yang tidak diteliti dalam penelitian ini.

\section{$\mathbf{Y}_{1-} \mathbf{Y}_{2}$ Kinerja-Kepuasan Kerja}

Berdasarkan analisis deskriptif, rata-rata skor kepuasan kerja sebesar 3,75 masuk pada interval 3,40 - 4,19 dengan inter prestasi Baik artinya mayoritas karyawan merasa puas dengan pekerjaan yang dijalani nya 
Dari hasil uji validitas istrumen kuisioner no 1 diperoleh nilai $\mathrm{r}_{\text {hitung }}>$ $\mathrm{r}_{\text {tabel }}$ dimana 0,760>0,300 dan untuk instrument no 2-10 pun dinyatakan valid.

Dari hasil uji reliabilitas diperoleh nilai $R_{\text {ca }} 0,880$ sehingga $0,880>0,600$ maka kuisioner varariabel kepuasan kerja dinyatakan reliabel

$\mathrm{Y}_{1}=36,650+0,219$ Dimana: $\mathrm{a}=$ 36,650 merupakan nilai konstanta, jika kinerja karyawan dianggap tidak ada maka nilai kepuasan sebesar 36,650 dan $b_{1}=0,219$ koefisien regresi variabel kinerja karyawan sebesar 0,219 artinya jika kinerja karyawan mengalami peningkatan satu-satuan maka kepuasan kerja mengalami peningkatan sebesar 0,219 dan koefisein regresi bernilai positif artinya terjadi hubungan positif antara kinerja karyawan dan kepuasan kerja dimana semakin baik kinerja karyawan maka semakin puas karyawan terhadap hasil kerja yang diperoleh nya.

Berdasarkan tabel tersebut maka dapat dilihat nilai $\mathrm{t}$ hitung $>\mathrm{t}_{\text {tabel }}$ dan nilai sig $<0,05$ sehingga 2,613 > 2,021 dan $0,001<0,05$ maka $\mathrm{Ha}_{3}$ diterima dan $\mathrm{Ho}_{3}$ ditolak. Hal ini sejalan dengan penelitian dari Mukti, dkk (2013), Agus dkk (2016).

Berdasarkan summary maka dapat diketahui nilai $r$ square adalah 0,424 hal ini berarti kinerja karyawan mempunyai kontribusi sebesar $42,4 \%$ terhadap variabel kepuasan kerja. Sisanya $57,6 \%$ dipengaruh oleh factor lain yang tidak diteliti dalam penelitian ini.

\section{PENUTUP}

\section{Kesimpulan dan Saran \\ Kesimpulan}

Berdasarkan rumusan masalah yang ada, maka diperoleh kesimpulan diantaranya:

a. Besarnya pengaruh kepemimpinan terhadap kinerja adalah 6,786, hal ini dilihat dari nilai $\mathrm{t}_{\text {hitung }}>\mathrm{t}_{\text {tabel }}$ dan nilai sig $<$ 0,05 sehingga $6,786>2,021$ dan $0,000<0,05$.

b. Besarnya pengaruh kepemimpinan terhadap kepuasan kerja adalah 4,864 hal ini dilihat dari nilai $\mathrm{t}_{\text {hitung }}>\mathrm{t}$ tabel dan nilai sig $<0,05$ sehingga 4,864>2,021 dan $0,003<0,05$.

c. Besarnya pengaruh kinerja karyawan terhadap kepuasan kerja adalah 2,613 hal ini dilihat dari nilai $\mathrm{t}_{\text {hitung }}>\mathrm{t}$ tabel dan nilai sig < 0,05 sehingga $2,613>2,021$ dan $0,001<0,05$.

\section{Saran}

a. Pihak perusahaan harus lebih meningkatkan kepemimpinan atau atasan dimana atasan yang datang tidak tepat waktu juga harus mendapatkan sangsi agar dapat memberikan contoh yang baik kepada bawahanya

b. Karyawan harus dapat meningkatkan kinerja degan menggunakan metode baru atau melakukan inovasi terhadap pekerjaanya dengan merubah cara kerjanya agar lebih baik lagi sehinggan tidak merasa jenuh dengan pekerjaan yang di lakukannya sehari-hari.

c. Karyawan yang merasa tidak puas dengan pekerjaan yang dijalani maka dari itu sebaiknya pemimpin dapat memberikan masukan lebih baik lagi kepada karyawanya agar dapat menyelesaikan pekerjaan sesuai dengan tujuan dan 
memberikan sangsi jika masih terdapat karyawan

\section{DAFTAR PUSTAKA}

Akhmad F. 2016. "Pengaruh Kepemimpinana dan Motivasi Kerja Terhadap Kinerja Pegawai Bagaian Hukum Sekretariat Daerah Kota Samarinda". Junrla Administrative. Fakultas Ilmu Sosial dan Ilmu Politik. Universitas Mulawarman

Agus, et al. 2016. Jurnal Bisnis Universitas Pendidikan Ganesha Jurusan Manajemen. Singaraja.

Ahmadi, Candra \& Dadang Hermawan. 2013. E-Business dan E-Commerce. Penerbit Andi. Yogyakarta.

Anwar Prabu Mangkunegara, 2010, Manajemen Sumber Daya Manusia Perusahaan, Remaja Rosdakarya, Bandung.

Bambang Supomo dan Nur Indriantoro, 2002, Metodologi Penelitian Bisnis, Cetakan Kedua, Yogyakara; Penerbit BFEE UGM.

Edy Sutrisno, 2014, “ Manajemen Sumber Daya Manusia" Jakarta : Kencana

Ferry. S. 2017. "Pengaruh Pengembanagan Karir dan Kepemimpinan Terhadap Kepuasan Pegawai Pada Badan Pelaksanan Penyulushan dan Ketahanan Pangan Kota Sungai Penuh". Jurnal Benefta. Sekolah Tinggi
Ilmu Ekonomi Sakti Alam Kerinci. Jambi.

Hasibuan, Malayu S.P., 2011. Manajemen Sumber Daya Manusia. Bumi Aksara, Jakarta

I Nyoman. 2016. " Pengaruh Kompensasi, Kepemimpinan dan Lingkungan Kerja Terhadap Kinerja Karyawang Pada Hotel Griya Santrian". Jurnal Mananjemen. Fakultas Ekonomi dan Bisnis Universitas Udayana, Bali.

Kadek. 2017. " Pengaruh Kepemimpian dan Disiplin Kerja Terhadap Kepuasan Kerja dan Kinerja Pegawan Negeri Sipil Pada Dinas Sosial Dan Tenaga Keraj Kabupaten Bandung". Jurnal Jagadhita. Junral Ekonomi dan Bisnis. Universitas Warmadewa. Bandung.

Kreitner, Robert dan Angelo Kinicki. 2014. "Perilaku Organisasi". Jakarta: Salemba Empat.

Moeheriono. 2012. "Pengukuran Kinerja Berbasis Kompetensi". Jakarta: Raja Grafindo Persada.

Muhammad.S. 2015. " Pengaruh Kepemimpian Terhadap Kepuasan dan Kinerja Karyawan PT Bank Tabungan Negara (Persero) Cabang Makassar". Makassar.

Mukti, et al. 2013. "Pengaruh Kepuasan Kerja Terhadap Kinerja Pegawan Pada Badan Ketahan Pangan Pelaksana Penyulusahan Daerah Kota 
Samarinda".

Ejournal

Administrative Reform. Ilmu

Adminstrasi. Universitas

Mulawarman, Kalimantan

Timur.

Richard L. Hughes, Robert C Ginnett, \& Gordon J Curphy, 2012, "Leadership Enhancing the Lessons of Experience - Memperkaya Pelajaran dari Pengalaman" Edisi 7, Jakarta : Salemba Humanika.

Rivai,Veithzal, "Commercial dkk.2012.

Bank
Management: Manajemen Perbankan Dari Teori Ke Praktik". Edisi 1. Jakarta: Rajawali Pers.

Rommy, Beno. 2016. "Pengaruh Kepemimpinan, Motivasi dan Disiplin Kerja Terhadap Kinerja Pegawai Pada Kanwil Ditjen Kekayaan Negara Suluttenggomalut". Jurnal EMBA. Fakultas Ekonomi dan Bisnis . Universitas Sam Ratulangi Manado. Sulawesi Utara. 